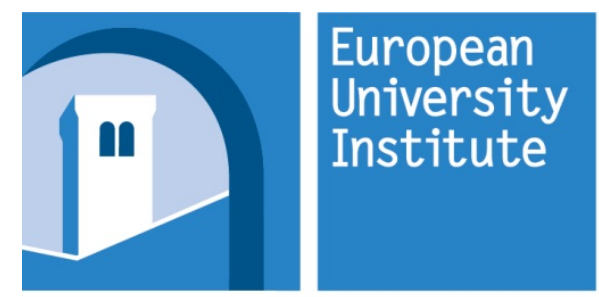

MAX WEBER

PROGRAMME

FOR

POSTDOCTORAL

STUDIES
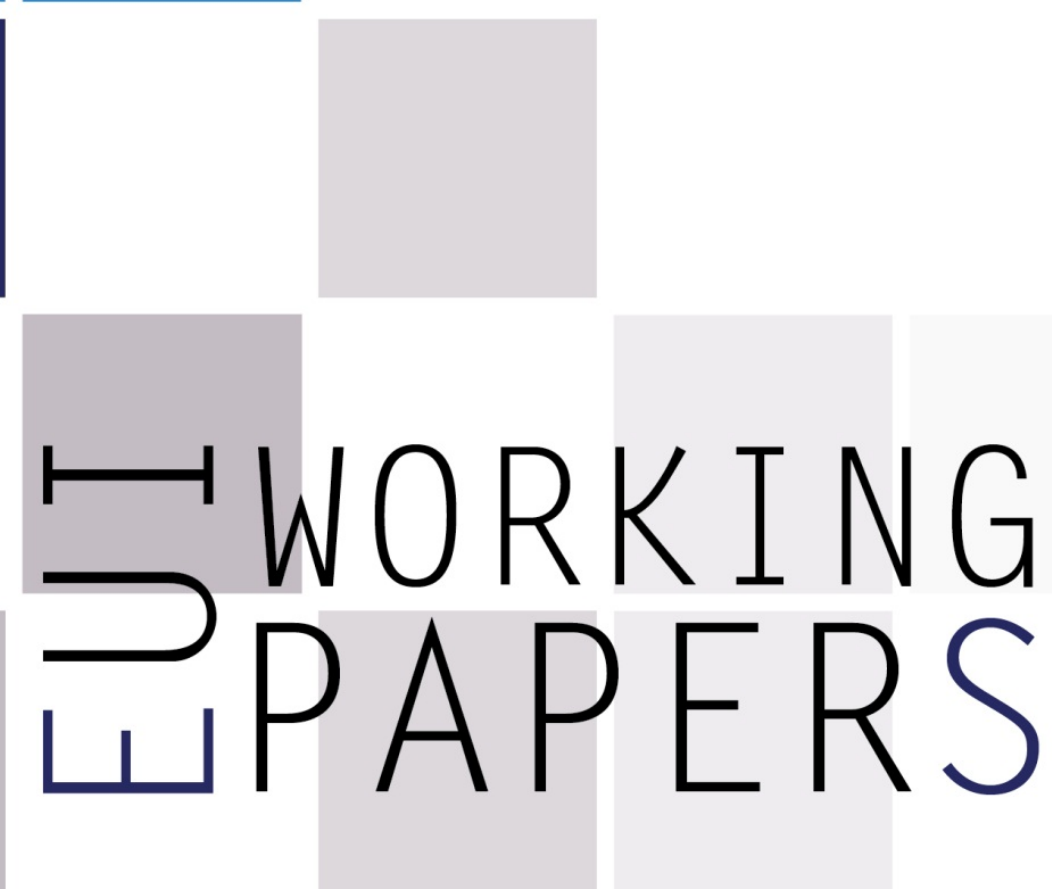

MWP 2015/01

Max Weber Programme

A Global Cross-border Insolvency Framework for Financial Institutions

Annika Wolf 

European University Institute Max Weber Programme

\section{A Global Cross-border Insolvency Framework for Financial} Institutions

Annika Wolf

EUI Working Paper MWP 2015/01 
This text may be downloaded for personal research purposes only. Any additional reproduction for other purposes, whether in hard copy or electronically, requires the consent of the author(s), editor(s). If cited or quoted, reference should be made to the full name of the author(s), editor(s), the title, the working paper or other series, the year, and the publisher.

ISSN $1830-7728$

(C) Annika Wolf, 2015

Printed in Italy

European University Institute

Badia Fiesolana

I - 50014 San Domenico di Fiesole (FI)

Italy

www.eui.eu

cadmus.eui.eu 


\begin{abstract}
The recent financial crisis has shown that national frameworks have been insufficient to stem the cross-border effects of the failure of a systemically important financial institution. This paper refers to the challenges for governments, in the aftermath of the financial crisis starting in 2007/2008, to provide stability in financial markets and the role of financial institutions for national economies and on a global scale. It discusses the need for coordinated action to resolve SIFIs by evaluating the regional approaches in Europe and the US, as well as considering the recommendations of four international bodies on the insolvency of large and complex financial institutions: the Financial Stability Board, the United Nations Commission on International Trade Law, the International Monetary Fund and the Basel Committee on Banking Supervision. The paper argues that key implications need to be recognized in order to make a global cross-border insolvency framework work effectively to coordinate around another Lehman-like event. It concludes that much has been discussed and initiated in the last six years, however, many issues are still unsolved. While single measures with a regional character are fit and comprehensible as a starting point, the pursued goal should be a mandatory and internationally consistent, homogenous cross-border insolvency framework since the interconnectedness of global financial institutions and their importance for financial stability will make it very difficult to prevent the next crisis and its disruptive impact.
\end{abstract}

\title{
Keywords
}

Cross-border Insolvency, Resolution, Financial Institutions, European Union, United States

\section{Annika Wolf}

Max Weber Fellow, 2013-2014 and 2014-2015. 



\section{Table of contents}

Introduction 1

I. The Role of Financial Institutions for National and Global Welfare ................................................

II. The Challenges of Distressed Financial Institutions ............................................................. 3

III. The Need for an Effective Cross-Border Insolvency Framework ................................................ 4

IV. Regional Approaches for Resolution ................................................................................ 7

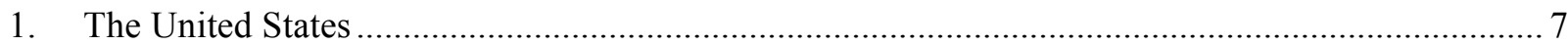

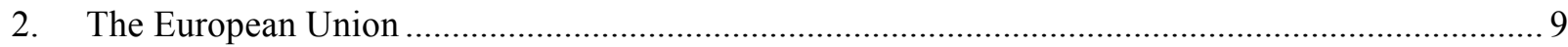

V. International Approaches for Resolution ........................................................................ 11

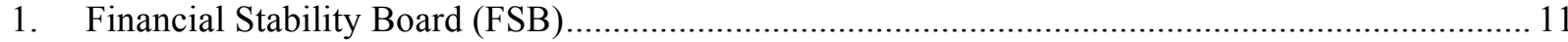

2. United Nations Commission on International Trade Law (UNCITRAL) ................................ 12

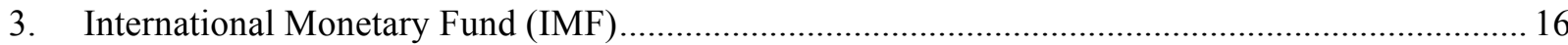

4. Basel Committee on Banking Supervision (BCBS) …................................................... 13

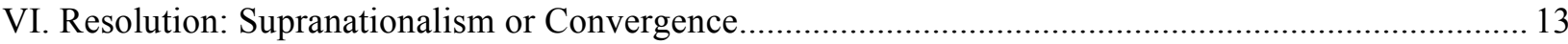

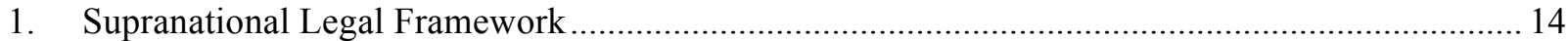

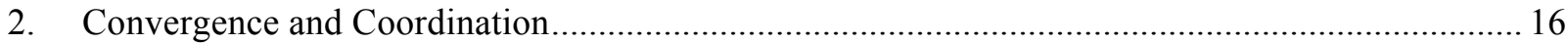

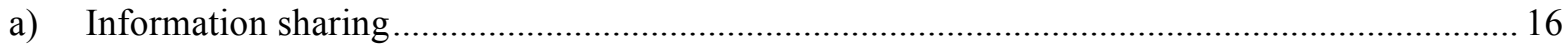

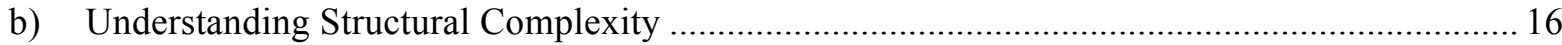

c) Location of the Centre of Main Interest (COMI) ...................................................... 17

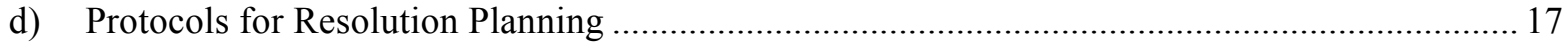

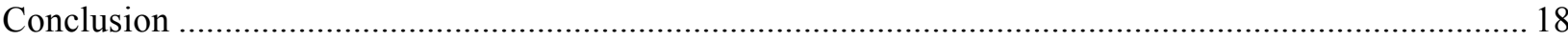

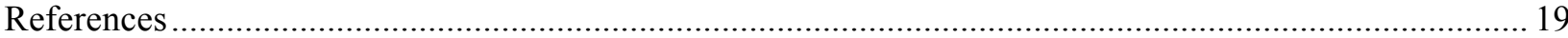





\title{
Introduction
}

\begin{abstract}
Bank failures [...] are almost a certainty at some time in our future. What is less certain is their cost to and adverse implications for macroeconomics. Past failures have frequently been resolved only at a very high cost to society, but they need not be. As with many things, the cost could be reduced through planning ahead in good times and having a well-developed, credible, and widely publicized plan ready to [be] put into action by policymakers when the need arises. The plan should be widely publicized in advance, both banks and their consumers, as well as regulators, can take it into account in their planning and behavior and [so] it [will] not [be] a surprise that is likely to upset people who [might] then claim that they were treated unfairly. ${ }^{1}$
\end{abstract}

Despite all the discussions on the consequences of the failure of a large, complex, international systemically financial institution (SIFI) ${ }^{2}$ - the need for orderly liquidation, for effective regulation and supervision, ${ }^{3}$ and the fact that a lot has been written on the topic, ${ }^{4}-$ not much substantive and coherent international groundwork was achieved before, or even after, the unexpected bankruptcy of Lehman Brother Inc. sent shockwaves into the financial markets. ${ }^{5}$ Whether the trigger for the financial crisis was the burst of the housing market bubble in the US, Lehman Brothers' filing for bankruptcy in the early hours of September $15^{\text {th }} 2008$ or uncertainties in the market about government support for SIFIs "too big to fail" (TBTF), ${ }^{6}$ is a somewhat philosophical discussion as it will not change the result of those days: a massive disruption of the financial system, damage to the trust of market participants that led to liquidity drying up and market participants ceasing to directly lend to each other, credit spreads shooting through the sky and banks writing off debts to adjust to their market value. Governments around the world acted quickly to release pressure from their national financial institutions and to contain the damage. ${ }^{7}$

It did come as a surprise to most market participants that Lehman Brothers was not rescued but was made to fail. Failures of banks, however, are not new. ${ }^{8}$ The word has it origins in the Italian medieval phase "banca rotta" (broken bench): when a banker was no longer able to exercise his craft, his creditors broke the banker's table, signifying that the banker was insolvent. Even in modern times, financial institutions around the world have failed. ${ }^{9}$ In the US, though, the Livingston Doctrine ${ }^{10}$ had for centuries provided a gentlemen's agreement that no bank would be left to fail when the economic

\footnotetext{
${ }^{1}$ Evanoff and Kaufmann (2005), Preface, vii.

${ }^{2}$ Hüpkes and Devos (2010), mn. 17.05: "financial institutions, which may create systemic risk, a failure of one institution would cause in turn the failure of others because of reciprocal credit exposure."

${ }^{3}$ Among others: Evanoff and Kaufmann (2005); De Rosa (2003); Caprio Jr. et al. (2006); Fratianni et al. (2002); Barth et al. (2001); Giovanoli and Heinrich (1999); Caprio Jr. et al. (1998);

${ }^{4}$ Among others: Miller and Cafaggi (2013); Brummer (2012); Carmassi and Micossi (2012); Macdonald et al. (2012); Buckley andArner (2011); Hoflich (2011); Mitchell and Wilmarth (2010); Kolb (2010); Fiordelisi et al. (2010); Busch (2009).

${ }^{5}$ Admati and Hellwig (2013), Preface, ixff.

6 "Too big to fail" is an attribute referring to the likely consequences of a failure, and the liquidation of such an institution, being seriously contagious and leading to possible failures of other financial institutions, causing market disruptions resulting in damage to the overall economy by compromising the stability of the financial system as a whole. For the Domino effect, see Solidoro (2013), 187.
}

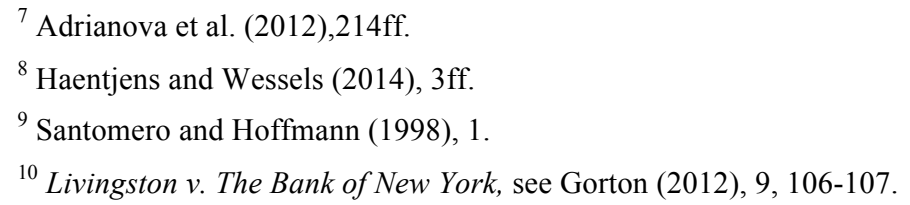


situation was in a state of public distress. ${ }^{11}$ The weekend before Lehman Brothers was doomed to fail, Bear Stearns was sold in a fire sale to JPMorgan, while Merrill Lynch was acquired by the Bank of America. A day after the Lehman Brothers collapse, the American Insurance Group (AIG) was rescued by the government. An additional failure would probably have caused not only more market disruptions but would have led to a failure of the financial system as a whole. Financial institutions are still attributed an important role in national economies and overall welfare on a global scale. This is one of the reasons why the government stepped in to bail out SIFIs. The outcome of the financial crisis was a great loss of confidence in the design of the global financial system and the efficient market hypothesis ${ }^{12}$. Intervention into markets is a distortion of competition. Market discipline with regard to the resolution mechanism is only effective when the framework is able to protect insured depositors, impose losses on the unsecured while ensuring the continuity of the essential banking services.

This paper takes a brief look at the role of financial institutions for the real economy and national welfare, followed by the challenges experienced with TBTF and the need for an effective cross-border insolvency framework. It will outline the backgrounds and resolution approach made by the European Union and the United States as well as the international approaches to deal with these institutions in a possible distress situation in future. The paper disregards the regulatory race of qualitative and quantitative measures (capital liquidity, ratios, and financial transaction taxes) but does focus on the measures and possible legal norms to implement a global cross-border insolvency framework for financial institutions that allows for effective resolution. If we want to restore trust and confidence in the financial market and its actors, there is a need for legal certainty: the need to know that when such failures come to pass, we will know ahead of time how to deal with them.

\section{The Role of Financial Institutions for National and Global Welfare}

The notion of a financial institution in distress ${ }^{13}$ has a more contagious impact than a corporation in distress of comparable size because of its public function for an economy. ${ }^{14}$ The view is that banks are special when compared to other organizations. ${ }^{15}$ A financial institution - the larger the institution, the greater the likelihood - is more vulnerable to the loss of public confidence as the lack of trust and confidence in the viability of its business generally ends its operational and economic survivability. ${ }^{16}$ The public trust in financial institutions is generated by their economic functions. These are, among others, the intermediary functions of maturity transformation, size transformation, currency transformation and - most importantly - the function to provide the real economy with the necessary liquidity (credit) to facilitate economic growth. ${ }^{17}$

\footnotetext{
${ }^{11}$ Gorton (2012), 122. purchases (at least $5 \%$ of GDP); deposit freezes.

${ }^{14}$ Hüpkes and Devos (2011), 17.08.

${ }^{15}$ Among others, Corrigan (1983), see also Hüpkes and Devos (2011), 17.07.

${ }^{16}$ Huertas (2011), 9. Santomero and Hoffmann (1998), 4, 5.

${ }^{17}$ Santomero and Hoffmann (1998), 2, 3.
}

${ }^{12}$ Brealey and Myers (1984), 784. Efficient market hypothesis, which "merely implies that competition in capital markets is very tough - there are no money machines, and security prices reflect the true underlying value of assets [...therefore] financial managers assume that capital markets are efficient unless they have a strong, specific reason to believe otherwise. This means trusting market prices and trusting investors to recognize true economic value." See also Grossman and Sticklitz (1980), discussing the idea that if everyone blankly assumes that the market is efficient and will not take any action to exploit it, then it will become efficient. For more on efficient markets, see Fama (1970).

${ }^{13}$ Laeven and Valencia (2010). Financial distress is considered when there are significant signs, e.g.: bank runs; or, in response to losses, significant policy intervention measures are adopted. At least three of the following measures are used to determine the significance: extensive liquidity support (5\% of deposits); payment of bank restructuring costs (at least $3 \%$ of GDP); bank nationalizations, mainly including cases where the government takes a majority stake in the capital of systemically important financial institutions; creation of guarantees on bank liabilities indicating that either a full protection of liabilities has been issued or guarantees have been extended to non-deposit liabilities of banks; asset 
We must note, however, that financial institutions have become more than only intermediaries; most institutions considered SIFI or TBTF as conglomerates with their main focus on investment banking. ${ }^{18}$ In order to maintain trust in the onset of the financial crisis in 2008, governments stepped in to rescue financial institutions that were TBTF; the government intervened in the market by bailing out financial institutions, making direct capital contributions, and providing loans from public funds or explicit state guarantees. Such state intervention came with a price tag. In a functioning and efficient market economy with self-regulating market power $^{19}$, viable companies survive while unviable companies eventually fail and disappear. In the case of financial institutions, governments in many countries have provided an implicit guarantee for rescue measures in the event of financial distress. The downside of such rescue assurance has led to moral hazard ${ }^{20}$ : setting the wrong incentives for financial institutions and encouraging negligence and unreasonable hazardous risk tolerance, which raises the risk of competitive distortions, has resulted in decreased confidence and legal uncertainty in the financial market sector until today. ${ }^{21}$

\section{The Challenges of Distressed Financial Institutions}

Regulation of the financial industry has occurred in waves on a national level as well through international initiatives (e.g. Basel Accords by the Bank of International Settlement). Regulatory action is the consequence of a crisis situation, whereas long and stable periods of regulation were followed by long periods of inattention and, after decades without major systemic risk or contagious events, subsequently, deregulation. This deregulation may lead to excessive risk taking, the growth of speculative bubbles, or waves of overconfidence and complacency, resulting again in financial regulatory action to close the gaps that initiated and contributed to the crisis.

Though history has been repeating itself, the major challenge in the aftermath of 2008 was that there was no orderly liquidation or resolution procedure in place for large cross-border operating financial institutions - despite discussions on, and forecasts about, the consequences that may arise when a SIFI / TBTF financial institution becomes financially distressed and could eventually fail. ${ }^{22}$ This challenge is even greater when financial institutions operate across borders, in different jurisdictions. ${ }^{23}$ The corporate structure of such an institution is designed to optimize the economic return to the group with a mix of regulated and unregulated entities. ${ }^{24}$

${ }^{18}$ Claessen, Herring, Schoenmaker (2010), p. 58, Fn. 55: Bank of America (primarily a bank, but also an investment bank); Citigroup (a bank, investment bank and insurance company); Goldman Sachs \& Co. (a bank holding company, migrating a portion of its derivatives portfolio to the bank, a broker-dealer (repo), and other corporations); J.P. Morgan Chase Bank (primarily a bank and investment hank); Morgan Stanley (a bank holding company migrating a portion of its derivatives portfolio to the bank, a broker-dealer (repo) and other corporations); Wells Fargo (a bank); also major custodians that operate as banks, including the Bank of New York Mellon, Northern Trust, PNC Financial Services Group, and State Street Corporation.

${ }^{19}$ See fn. 12.

${ }^{20}$ Santomero and Hoffmann (1998), 11.

${ }^{21}$ It seems that the news of scandals that various international financial institutions have engaged in is endless e.g. exchange rate or LIBOR fixings, gold standard irregularities, which have deepened to a lack of trust in the financial industry.

${ }^{22}$ Crocket, in: Evanoff and Kaufmann (2005), $17 \mathrm{ff}$.

${ }^{23}$ Fletcher (1992), IX: "Cross-Border insolvency is the expression frequently employed to designate those causes of insolvency where the assets, or liabilities, of an insolvent debtor are located in two or more separate jurisdictions, or where the circumstances of the debtor are such as to render the company simultaneously subject to the insolvency laws of more than one country."

${ }^{24}$ Lehman Brothers Inc. Group consisted of 2,985 legal entities, operating in 50 countries, see Basel Committee on Banking Supervision, Report and Recommendations of the Cross-border Bank Resolution Group, March 2010, p. 14, mn. 49. 


\section{The Need for an Effective Cross-Border Insolvency Framework}

"Bankruptcy is a backup" 25 since "[t]he rule must still be that debts are meant to be repaid in full",26

Even though insolvency is supposed to be a backup, having a procedure in place is necessary in the event of a default, in order to allow for an effective and fast way to resolve both corporate companies and financial institutions. However, general corporate insolvency law is unable to deal with insolvent financial institutions. While corporate insolvency law generally aims at the fair treatment and maximization of creditor recovery in slow, court-based proceedings with lengthy negotiations among stakeholders, resolution of financial institutions aims at minimizing disruption to the financial system and preserving the continuity of banking operations in order to avoid a systemic banking crisis. The crucial importance of this objective, that would ideally drive a special resolution regime, should limit the influence of private parties (e.g. creditors' rights). This applies even more to cross-border insolvency cases, which are quite a daunting challenge. Although some countries have already established a national framework to resolve financial institutions, these do not adequately address the resolution of financial institutions TBTF. ${ }^{27}$

The various legal procedures and substantive legal provisions are not only derived from their historical contexts, attitudes and values ${ }^{28}$ but are also rooted in social, economic, or political factors important to societal life. ${ }^{29}$ Different statutory objectives between different jurisdictions invariably relate to the fundamental rules and principles of a nation. ${ }^{30}$ However, law is not always capable of solving effectively all the challenges it is presented with, and since "Law is power. Law is politics" ${ }^{31}$, the political power and the influence of interest groups on the political will ${ }^{32}$ should not be underestimated in making law, ${ }^{33}$ especially for strong lobbying industries like financial institutions and insurance companies. The bail-out of many financial institutions during the crisis was an achievement of political will rather than economic logic.

With no resolution plan in place when a complex financial institution approaches insolvency, political pressure will rise to influence any response of regulators to provide a solution to the challenge:

Minimizing immediate short-run costs is likely to outweigh minimizing later longer-run and longer-lasting costs, even if these delayed costs promise to be substantially greater. Stated differently, today will win out over tomorrow and politics will trump economics. ${ }^{34}$

The best case scenario would be that supervisory authorities and central banks could ensure the maintenance of a robust financial system by providing adequate capital cushions to absorb any market disruptions and thereby avoid spillovers that threaten financial stability. In the case of a probable default event of a cross-border financial institution, supervisory authorities should also provide for an

\footnotetext{
${ }^{25}$ Easterbrook (1990), 416.

${ }^{26}$ Cárdenas, in Buljevich (2005), xx

${ }^{27}$ The UK Banking Act, which was introduced to Parliament on 7th October 2008 (see also Claessens, Herring, Schoenmaker (2010), 113ff.) or the German Gesetz zur Reorganisation von Kreditinstituten, introduced on 9. December 2010 BGB1. I S. 1900.

${ }^{28}$ Finch (2010), 521.

${ }^{29}$ Watson (1983), 1134ff.

${ }^{30}$ Fletcher (1992), Preface, X.

${ }^{31}$ Watson (1983), 1125.

${ }^{32}$ Wilks (2013), 11.

${ }^{33}$ Watson (1977), 9 whereas "various interests of groups and individuals" may be "very active in preserving [rules suiting them]". See also Renner (2011), $111 \mathrm{ff}$. that the legal system must maintain its structural couplings to the political system and thereby find ways for transnational legal structures to reflect domestic, supranational and international discourse alike. In addition Grant and Wilson (2014), Preface viii: legislation requires also great political and tactical skill.

${ }^{34}$ Evanoff and Kaufmann (2005), Preface, vii-viii.
} 
immediate and effective response to the crisis - often within hours if disruptions are to be minimized. This is in contrast to most bankruptcy proceedings of corporations, where the opening of the proceedings leads to an automatic stay, protecting the status quo of the debtor and enabling the administrator to collect and realize the assets. In any case, the resolution plan asked for by regulators and supervisors to prepare for the case of bankruptcy of financial institution will provide the necessary information on, and clarity about, the corporate structure of a complex financial conglomerate, avoiding a last-minute attempt to formulate and execute a resolution plan $^{35}$ whereby a substantial value of the bankruptcy estate could be rescued. ${ }^{36}$ Since many financial institutions have become much too complex to be taken through any kind of resolution procedure in a reasonable amount of time, it seems naive to expect these firms to willingly give up complexity, a complexity that assures them access to (government) subsidies providing them with a safety net and therefore a competitive advantage over other smaller, less complex institutions. It is important that the process of resolution planning produces demonstrable improvements in the resolvability of these institutions and reduces complexity.

When the first line of defense protecting the integrity of the financial system fails, a cross-border insolvency proceeding provides the second line of defense, while the insolvency framework should recognize the waterfall of losses, beginning with shareholders and creditors who have been paid to take the risk, and protect taxpayers and other potential sources of bailout funds from loss. A good cross-border insolvency framework should deliver predictable ex post efficient results that maximize the value of the bankrupt business for the satisfaction of creditors and other stakeholders. However, during the recent financial crisis, national authorities either used public money to bail out banks, or ring-fenced the assets belonging to a bank within their territory. ${ }^{37}$ They applied national resolution measures at the single-entity level rather than considering the cross-border perspective of the financial conglomerate. ${ }^{38}$

An effective cross-border insolvency law to allow for the orderly resolution of a financial institution is important for both debtors and creditors. It should create legal certainty when dealing with financial institutions TBTF, thereby preventing public funds being spent to avoid a financial meltdown. As I have just said, the failure of financial institutions and their structural vulnerability in the financial system has long been on the policy agenda of governments and policymakers around the world, as they stand at the center of the international payment system, on a daily basis channeling transactions that represent large multiples of their capital. In the event of default, the transactions would be stopped, leading to no more payments, causing a huge erosion of liquidity in the system resulting in failed payments for a wide range of transactions. These would put the solvency of other parties and financial institutions at risk. The main challenge for resolution planning is therefore to create a system capable of allowing the failure of individual financial institutions while preserving global economic and financial stability.

Despite the fact that maintaining a sound and efficient financial system able to effectively respond to a market disruption is a crucial prerequisite for a country's economic and social welfare, a single uniform, formalized, operationally and legally robust international approach has not yet been achieved as actions have been limited to within national borders. This leaves many questions open: Why has it not been agreed upon yet? Haven't we talked about this issue since the beginning of the almost - meltdown? What is it that governments and policymakers are not able to agree on a cooperative approach that would be beneficial for all parties involved? What are the reasons? Only politics? And this is despite the fact that governments, policymakers, and the managers of financial institutions know about the importance of creating more certainty to be prepared for the next crisis. Or

\footnotetext{
${ }^{35}$ Claessens, Herring, Schoenmaker (2010), 58ff. See also Hüpkes (2009), 515: "policy-makers need to give more attention to how the complexity of an institution's legal structure affects the resolution process as this makes a rapid and orderly wind-down virtually impossible; merely the size of an institution is the wrong feature to consider."

${ }^{36}$ Cairns (2009): the administrators of Lehman Brothers handling the bankruptcy estimated a loss of at least USD75 billion due to the lack of any preparation for bankruptcy.

${ }^{37}$ Hüpkes and Devos (2011), 17.09, also on supervisory ring-fencing, 17.12ff.

${ }^{38}$ Hüpkes and Devos (2011), 17.10.
} 
do we believe that all measures agreed upon today will not hold in the future as every crisis is different? All these questions show that reaching mutual agreement on a basic cross-border resolution framework still represents a big challenge despite the efforts made by international institutions in previous years. ${ }^{39}$

However, one should keep in mind that the Lehman Brothers bankruptcy proceeding has clearly shown that winding up large and complex international financial institutions is a messy business. ${ }^{40}$ Despite the fact that the discussion evolved around financial institutions TBTF, larger complex institutions have become even bigger because of the ongoing consolidation in the financial industry: Bank of America has acquired Merrill Lynch, JPMorgan Chase has taken over Bear Stearns and Barclays Bank has acquired the investment banking arm of Lehman Brothers out of the bankruptcy estate. The argument, however, seems to be true only for the US. The banking industry in the Eurozone is decreasing. ${ }^{41}$ This is, however, not because of any (usually cross national) mergers, which have only happened sporadically in the past, ${ }^{42}$ but because of the decreasing balance sheets of European Banks.

\section{Regional Approaches for Resolution}

\section{The United States}

Financial regulation and supervision has been on the US agenda since 1933.

The United States recognized a long time ago the need to regulate banks differently to corporates. In 1933, the Glass-Steagall $\mathrm{Act}^{43}$ distinguished commercial banks, investment banks, and insurance companies, as it was believed that commercial banks' securities operations had caused the stock market crash in 1929, thanks to the insider trading of securities. The act was created in "response to an incentive failure and recognition of the realities of the opportunities for bad behavior when incentives are not aligned properly" 44 . It introduced the Federal Deposit Insurance Corporation (FDIC), which had to ensure that depositors have prompt access to insured deposits and that a systemic threat of a failure is contained. The FDIC has a broad range of powers to repudiate contracts and transfer positions to other banks, as well as options for dealing with a bank failure, including liquidation, arranging a purchase and assumption transaction with another institution, establishing a conservatorship, providing open bank assistance or creating a bridge bank. ${ }^{45}$ With the desire to deregulate the financial industry, the Gramm-Leach-Bliley Act $^{46}$ effectively repealed the Glass-

\footnotetext{
${ }^{39}$ See Section V.

${ }^{40}$ Claessens, Herring, Schoenmaker (2011), 42ff. for case studies of cross-border bank failures.

${ }^{41}$ FAZ (06.11.2013), 18: "The number of financial institutions in the Eurozone has decreased from 2008 until 2012 by $9 \%$ to 5914, this refers to a decrease in balance sheet of $12 \%$. Germany and France remain the biggest national banking markets with Spain and Italy following."

${ }^{42}$ Solidoro (2013), 191, mentions the takeover of Erste Bank in Austria and Hypobank in Germany by the Italian Unicredit, and the takeover of the UK Abbey National by the Spanish Santander. FAZ (06.11.2013): "National takeovers are rather rare, Commerzbank and Dresdner Bank in Germany one of the exception. In the course of the crisis, however, the markets in Greece and Spain consolidated by regional takeovers." For the merger option, see also Santomero and Hoffmann (1998), 9ff.

${ }^{43}$ Banking Act of 1933, Pub.L. 73-66, 48 Stat. 162, H.R. 5661, 16 June 1933.

${ }^{44}$ Shiller, in Kroszner and Shiller (2011), p. 19.

${ }^{45}$ A bridge bank is a temporary national bank organized by the FDIC to take over and maintain banking services for the customers of a failed bank. It is designed to bridge the gap between the failure of the bank and the ultimate resolution, which is intended to happen as quickly as a suitable buyer can be found.

${ }^{46}$ The Gramm-Leach-Bliley Act was created to enhance competition in the financial services industry by providing a prudential framework for the affiliation of banks, securities firms, and other financial service providers, and for other purposes, Pub.L. 106-102, 113 Stat. 1338, 12 November 1999.
} 
Steagall Act in 1999 and allowed commercial banks to resume investment banking and to affiliate with insurance companies. ${ }^{47}$

US Congress enacted the Dodd-Frank Wall Street Reform and Consumer Protection Act $^{48}$ in 2010 as the "most ambitious regulatory reform since the Great Depression" ${ }^{49}$. Among others, ${ }^{50}$ Dodd-Frank established the authority for the Financial Stability Oversight Council to require systematically important nonbank financial companies and large "interconnected" bank holding companies to establish resolution plans for failing bank holding companies or other financial institutions, as well as the authority for the relevant government agencies to undertake prompt and orderly resolution, outside the ordinary corporate bankruptcy procedure.

This deregulation and the changing landscape of the interconnected business model may be one of the reasons why the FDIC was not able to deal with failing important US SIFIs despite having the powers and various instruments in place. One of the reasons was the court structure in the US. There is no mechanism in place that ensures effective coordination between courts that would have been necessary to deal with the failure of a SIFI. Corporation would also been accounted for with state insurance supervisors and the Securities Investor Protection Corporation (SIPC). Both seemed to be unwilling to transfer powers to the FDIC. Instead, they insisted, and still insist, on guarding the clients and customers they are required to protect.

Advocates of the FDIC suggest expanding its powers to make it a resolution agency capable of dealing with SIFIs: they would like to create an agency that would be able to shape many aspects of the resolution process, including the timing of closures and the choice of reorganization, liquidation or a pre-packaged resolution. ${ }^{51}$ It should have power to wipe out shareholders (except for residual value) and to allocate losses (or protection from losses) across and within creditor classes with the flexibility to maintain an orderly resolution. All of this is largely in Dodd-Frank. In addition, the FDIC should also have the ability to maintain critical systemically important services, such as to select the management while the SIFI is in the resolution, reorganization or bridge institution phase, and to have the ability to claw back funds that had been inappropriately transferred before the failure (which could of course include funds transferred internationally) while avoiding any second guessing by the courts. The FDIC should also have a pool of funds - collected from the SIFIs, not taxpayers - to cover losses not allocated to depositors or other creditors deemed necessary to prevent systemic risk. Dodd-Frank does not provide for an ex ante resolution fund but it provides for bail-in and contingency planning.

Being subject to Title II of Dodd-Frank, resolution is determined through a multistep process: whether the financial institution in question is a "covered financial company" 52 under the Dodd-Frank Act and whether its financial activity has been defined by the FDIC. There is only limited judicial review ${ }^{53}$ of the classification of the firm as a covered financial institution.

\footnotetext{
${ }^{47}$ Higgott, in Grant and Wilson (2013), 17.

${ }^{48}$ The Dodd-Frank Wall Street Reform and Consumer Protection Act was enacted so as to promote the financial stability of the US by improving accountability and transparency in the financial system, to end "too big to fail", to protect the American taxpayer by ending bailouts, to protect consumers from abusive financial services practices, and for other purposes, Pub.L. 111-203, H.R. 4173; herewithafter Dodd-Frank.

${ }^{49}$ Shiller, in Kroszner and Shiller, p. 2.

${ }^{50}$ E.g. creation of a Financial Stability Oversight Council and Bureau of Consumer Financial Protection; reallocation of banking oversight responsibility among the Federal Reserve System, the Controller of the Currency, and the Federal Deposit Insurance Corporation; changes requiring the Federal Reserve Board to supervise systemic nonbank financial companies; authority for regulators to impose enhanced size- and risk-based capital and liquidity standards those institutions deemed systematically important; and heightened capital requirements more generally.

${ }^{51}$ Claessens, Herring, Schoenmaker (2010), 80.

52 Expressly excluded from the definition of a covered financial company are all depository institutions, government sponsored enterprises, and any government entities.

${ }^{53}$ Fitzpatrick and Thomson (2011) "Judicial review utilizes an "arbitrary and capricious" standard - typical when reviewing decisions of administrative agencies - which essentially prevents the judiciary from overruling those determinations unless there was no reasonable basis for them. Its powers under the orderly liquidation authority mirror those it already
} 
Even though the Dodd-Frank Act attempts to provide for an orderly resolution procedure for financial institutions, it fails to provide a viable framework for resolving a complex cross-border financial conglomerate, taking into account a corporate structure which could also include a securities firm and/or an insurance company. In addition, advocates as well as critics have recognized the necessity of coordinated resolution activities with other foreign jurisdictions that may be affected by the FDIC's intervention; however, this would be very different to the current FDIC in terms of the scope of its domestic and foreign powers. On the bright side though, Dodd-Frank focuses on derivative contracts, placed onto platforms with central counterparties, thereby improving the infrastructure for resolution. However, it leaves much implementation to be determined by the rulemaking regulators and supervisors.

At the forefront of resolution planning, the Federal Reserve Bank and the FDIC have taken sharp measures to ensure that the living wills portray reality when they neglected the wills of eleven financial conglomerates as not sufficient enough and requested amendments. ${ }^{54}$

\section{The European Union}

While the European Union concentrated on creating the internal market and achieving the monetary union, the establishment of the banking union was neglected, leading thus to many regulatory actions in order to cope with the aftermath of the 2008 financial crisis.

Various Member States in the European Union bailed out their banks in the aftermath of the crisis. The European legal experience, with financial institutions operating in different jurisdictions, has been challenging: indeed, to reach any common legal standard continues to be a significant challenge. Only a few years ago, European institutions adopted the 2001/24 Directive 2001/24/EC on the reorganization and winding up of credit institutions ${ }^{55}$ after more than a decade of negotiations. ${ }^{56}$ The crucial objective of this body of conflict-of-law rules consists in ensuring that when a European transnational bank fails, all creditors and investors are involved in a unified procedure. By applying the universality principle, this approach adheres to the recent trends that came out of the European debate on the matter. Yet, there were various shortcomings in the directive: For instance, it did not take into account a group or conglomerate structure, especially when a bank as a stand-alone entity can induce the failure of solvent subsidiaries which otherwise could have been reorganized and remained solvent. In addition to that, official administrators may face special difficulties in implementing certain recovery operations, such as 'purchase and assumption' transactions. ${ }^{57}$

In the aftermath of the financial crisis, the European System of Financial Supervision (ESFS) $)^{58}$ was implemented as the institutional framework, in an attempt to regain and ensure financial stability in achieving the common internal market. The European Supervisory Authorities (ESAs) ${ }^{59}$, constituting the European Banking Authority $(\mathrm{EBA})^{60}$, the European Insurance and Occupational

(Contd.)

has for depository institution receiverships, including the equivalent of bridge bank authority and the limited judicial review of its actions."

${ }^{54}$ FAZ 19.08.2014, 18. Another difficulty is that the Federal Reserve Bank and the FDIC has different standards in evaluating the living wills.

55 Directive 2001/24/EC of the European Parliament and the Council on the reorganization and winding up of credit institutions, OJ L 125/15, 05.05.2001, hereinafter Winding-Up Directive.

${ }^{56}$ Solidoro (2013), 193.

${ }^{57}$ Ibid., 187.

${ }^{58}$ Recital 5, Regulation 1095/2010/EU of the European Parliament and of the Council of 24 November 2010 establishing a European Supervisory Authority (European Securities and Markets Authority), OJ L 331, 15.12.2010.

${ }^{59}$ Recital 10, Regulation 1095/2010/EU of the European Parliament and of the Council of 24 November 2010 establishing a European Supervisory Authority (European Securities and Markets Authority), OJ L 331, 15.12.2010.

${ }^{60}$ Regulation 1093/2010/EU of the European Parliament and of the Council of 24 November 2010 establishing a European Supervisory Authority (European Banking Authority), OJ L 331, 15.12.2010, p. 12. 
Pensions Authority (EIOPA) ${ }^{61}$ and a European Securities and Markets Authority (ESMA) ${ }^{62}$ for microprudential supervision were given the authority to merge the different supervisory and regulatory approaches to financial institutions of the EU Member States. The European Systemic Risk Board (ESRB) for macro-prudential supervision, under the responsibility of the European Central Bank (ECB), complements the framework. ${ }^{63}$ The aim is to achieve an integrated banking union, providing a consistent and coherent framework for financial services within the Eurozone with a "single rulebook in the form of capital requirements [...] harmonised deposit protection schemes [...] and a single European recovery and resolution framework." ${ }^{, 64}$ Key elements of the integrated banking union are the single supervisory mechanism (SSM) ${ }^{65}$, while the ECB assumes responsibility for specific supervisory and regulatory tasks for SIFIs in the Eurozone ${ }^{66}$ and for the single resolution mechanism (SRM), including a single resolution fund ${ }^{67}$. More than anything else the SSM will help to strengthen coordination, information sharing, and decision making in relation to cross-border banks. ${ }^{68}$ This should also break the vicious cycle between banks and sovereign governments ${ }^{69}$ that is widely viewed as having played a major role in bringing about the Eurocrisis.

The single European recovery and resolution framework was implemented with the Directive 2014/59/EU establishing a framework for the recovery and resolution of credit institutions and investment firms ${ }^{70}$. It establishes the requirements for all European Member States and members of the European Free Trade Area (EFTA) national resolution frameworks, and aims to ensure that the financial institutions can be resolved in a timely manner, with minimal risk to financial stability and minimal losses borne by shareholders and creditors. There is no logical response to why such an important framework has been enacted by a directive and not by a regulation, which would be directly applicable in all Member States and could ensure more harmonization for the resolution of financial institutions.

The Directive 2014/59/EU covers credit institutions established in EU Member States, parent companies, (mixed) financial holding companies, investment firms, and other financial institutions established in the EU and subject to consolidated banking supervision. It provides for resolution powers, including rules relating to the early intervention and restructuring power as well as tools for the sale of an institution's business; transfer of assets and liabilities to a bridge institution; separation of assets for transfer to an asset management vehicle; and treatment of shareholder rights (bail-in), as well as creditors' rights and obligations, avoidance powers, treatment of intra-group claims, rights to set-off and netting, and the treatment of financial contracts. In particular, the bail-in tool can be used to

${ }^{61}$ Regulation 1094/2010/EU of the European Parliament and of the Council of 24 November 2010 establishing a European Supervisory Authority (European Insurance and Occupational Pensions Authority), OJ L 331, 15.12.2010, p. 48.

${ }^{62}$ Regulation 1095/2010/EU of the European Parliament and of the Council of 24 November 2010 establishing a European Supervisory Authority (European Securities and Markets Authority), OJ L 331, 15.12.2010, p. 84.

${ }^{63}$ Gurlit (2014) on a critical assessment of the division of power between the ECB and EBA and whether this will lead to competing supervisors.

64 "Commission proposes new ECB powers for banking supervision as part of a banking union" (Press release). Communication department of the European Commission. 12 September 2012. Accessed 05 October 2013.

${ }^{65}$ Council Regulation 1024/2013/EU of 15 October 2013 conferring specific tasks on the European Central Bank concerning policies relating to the prudential supervision of credit institutions, OJ L 287/63, 29.10.2013. See Schuster (2014), 3, 4ff. for institutions covered by the SSM and the banking supervisory powers and tasks of the ECB.

${ }^{66}$ Schuster (2014), 3: "a milestone in the integration of the European banking markets".

${ }^{67}$ For Eurozone Member States, national resolution funds will be pooled into the proposed EUR 55 billion single resolution fund to be operational by 2016. Contributions from banks are expected to be made over an eight-year period.

${ }^{68}$ Neumann (2014), $12 \mathrm{ff}$.

${ }^{69}$ Draghi (2012).

${ }^{70}$ Directive 2014/59/EU of the European Parliament and of the Council of 15 May 2014 establishing a framework for the recovery and resolution of credit institutions and investment firms and amending Council Directive 82/891/EEC, and Directives 2001/24/EC, 2002/47/EC, 2004/25/EC, 2005/56/EC, 2007/36/EC, 2011/35/EU, 2012/30/EU and 2013/36/EU, and Regulations (EU) No 1093/2010 and (EU) No 648/2012, of the European Parliament and of the Council Text with EEA relevance, OJ L 173, 12.6.2014, p. 190-348; herewithafter BRRD. 
recapitalize a failing institution, convert debt into equity, or reduce principal amounts on claims or debt instruments with the exception of specific ones, such as insured deposits and liabilities with a maturity of less than seven days. ${ }^{71}$ Other resolution powers allow resolution authorities to replace senior management, and to impose temporary stays on the payment of financial claims. It also requires financial institutions to prepare resolution plans. The resolution plans need to be approved by the ECB, which - after much debate on its responsibilities - has been given the power either to decide on the financial institution's viability or to facilitate its resolvability. It remains unclear however what will happen to subsidiaries outside the reach of the BRRD as there are no legal rules or recommendation covering that issue.

In the absence of agreement between an EU Member State and a non-EU resolution authority, e.g. Dodd-Frank Act in the US, decisions regarding the recognition of the non-EU authority's resolution proceedings may be taken by each national resolution authority. ${ }^{72}$

\section{International Approaches for Resolution}

It is neither possible nor desirable for each individual government to independently work out all the legal details for the resolution of financial institutions. In order for a global framework to be effectively implemented, multilateral economic organizations are a key element in the process ${ }^{73}$ and have been given the task to initiate an effective cross-border framework for the resolution of financial institutions to secure financial stability.

Most are set up as voluntary groupings rather than treaty-based institutions, and even those that do have a treaty basis (the Bank for International Settlements (BIS), the International Monetary Fund (IMF), the Organization for Economic Cooperation and Development (OECD) and the World Bank) have no enforceable financial regulatory mandate. The willingness of individual jurisdictions to respect the choices made by these global bodies is therefore essential. What follows is a discussion of the attempts of several international bodies to work out how to address the problem of the cross-border insolvency regime.

\section{Financial Stability Board (FSB)}

In 2009, the $\mathrm{G} 20^{74}$ gave the Financial Stability Board ${ }^{75}$ the task of finding a solution to cross-border insolvency of SIFIs within a year. This was rather optimistic considering the size, complexity and systemic interconnectedness of SIFIs.

${ }^{71}$ The BRRD introduces tiered depositor preference. The waterfall of creditor claims established is as follows: (i) covered deposits, and the deposit insurance scheme by virtue of subrogation to the rights of covered depositors; (ii) eligible deposits of natural persons and micro- and small and medium enterprises (SMEs) exceeding the deposit insurance coverage level; (iii) deposits in foreign branches of EU banks; (iv) claims of ordinary unsecured, non-preferred creditors; and (iv) shareholders.

${ }^{72}$ This provides more flexibility to EU authorities than under the Winding-Up Directive under which EU home authorities have exclusive competence in reorganization or winding-up measures relating to EU banks and their EU branches, with full recognition and legal effectiveness of such actions within the EU.

${ }^{73}$ Higott, in Grant and Wilson (2013), 16.

${ }^{74}$ The G20 was formed in 1999 and consists of Argentina, Australia, Brazil, Canada, China, the European Union, France, Germany, India, Indonesia, Italy, Japan, the Republic of Korea, Mexico, Russia, Saudi Arabia, South Africa, Turkey, the United Kingdom and the United States. Until November 2008, G20 meetings were held at the level of finance ministers and central bank governors and not heads of state and/or government.

75 The FSB includes Australia, Canada, France, Germany, Hong Kong SAR, Italy, Japan, the Netherlands, Singapore, Switzerland, the United Kingdom and the United States, as well as the European Central Bank and a number of global institutions and bodies. In 2009, Argentina, Brazil, China, India, Indonesia, the Republic of Korea, Mexico, Russia, Saudi Arabia, South Africa, Spain and Turkey as well as the European Commission were added. It also acts as a coordinator of the G20-related policy development processes of other global financial bodies, including the Basel Committee on Banking Supervision (BCBS), the Bank for International Settlements (BIS), the Committee on the Global Financial System (CGFS), the Committee on Payments and Settlement Systems (CPSS), the International Association of Insurance Supervisors (IAIS), the International Accounting Standards Board (IASB), the International Monetary Fund (IMF), the 
The FSB has extensively analyzed the challenges and, in 2011, the G20 leaders and the FSB drew up the Key Attributes of Effective Resolution Regimes ${ }^{76}$. These enable authorities to exercise a broad range of powers without the need to obtain the consent of shareholders or creditors, subject to appropriate safeguards ${ }^{77}$ among which are taking control of a failing financial institution, merging ailing banks with stronger institutions, and transferring assets and liabilities to a healthy institution (bridge bank). However, these key attributes are only recommendations and therefore non-binding standards. The peer review of national resolution schemes ${ }^{78}$ provides recommendations for future work by the FSB and its members, especially with regard to the effectiveness of national regimes for foreign resolution. ${ }^{79}$

Another aspect the G20 focuses on was the attempt to force the harmonization of accounting standards to "achieve a single set of high-quality, global accounting standards." ${ }^{80}$ In this regard, the G20 agenda has unambiguously failed as convergence projects have been conspicuously ignored by the independent accounting standard setters as the political will did not draw much pressure on these institutions. ${ }^{81}$

\section{United Nations Commission on International Trade Law (UNCITRAL)}

UNCITRAL has also been discussing the issue, raising questions of whether the adoption of a model law for the resolution of financial institutions - an equivalent to the cross-border model law for companies - would be an appropriate measure. However, one should keep in mind that despite there being a model law for the insolvency of companies only 20 nations have so far adopted this law. Discussions on recommendations are still on-going, however, another model law for financial institutions with far-reaching powers is not likely to be adopted by most nations.

\section{International Monetary Fund (IMF)}

The International Monetary Fund published its "Resolution of Cross-Border Banks - A Proposed Framework for Enhanced Coordination" ${ }^{\prime 22}$ in 2010. The main objective of the framework is the focus of coordinating and aligning resolution efforts with the main goal of achieving consistency with the interests of creditors and domestic financial stability, and while the need for public funding should be minimized, it may be provided on a temporary basis to support procedures for recovery/resolution of financial institutions. The report also delivers the factors for the globalization of financial services and recognizes increased cross-border effects while national frameworks address the financial distress and failure only for national territory.

(Contd.)

International Organisation of Securities Commissions (IOSCO), the Organisation for Economic Cooperation and Development (OECD) and the World Bank.

76 See FSB, Key Attributes of Effective Resolution Regimes for Financial Institutions, October 2011, http://www.financialstabilityboard.org/wp-content/uploads/r_111104cc.pdf?page_moved=1, accessed 15 May 2014.

${ }^{77}$ In particular, an ideal resolution regime should include: (i) stabilization options that achieve continuity of systemically important functions through sales or transfers of the shares in the firm or of all or parts of the firm's business to a third party, either directly or through a bridge institution; and (ii) liquidation options that provide for the closure and winddown of all or parts of the firm's business (in a manner that protects insured depositors, insurance policy holders and other retail customers).

${ }^{78}$ See FSB, Thematic Review on Resolution Regimes, 11 April 2013.

${ }^{79}$ Only eight jurisdictions have statutory provisions that explicitly empower or strongly encourage resolution authorities to cooperate with each other: Australia, New Zealand, Hong Kong, Indonesia, Japan, Spain, Switzerland, UK, and US. See Financial Stability Board, Thematic Review on Resolution Regimes, Peer Review Report, 11 April 2013.

${ }^{80}$ G20 announcement in 2008, see Accounting Standards Advisory Forum: Memorandum of Understanding, 8 April 2013 for action on global accounting standards in, http://www.ifrs.org/About-us/IASB/Advisory-bodies/Documents/20130408MoU-Signed.pdf, accessed 18 May 2014.

${ }^{81}$ Higgott, in Grant and Wilson (2013), $21 \mathrm{ff}$. on the failure of the FSB to gain some degree of global authority.

${ }^{82} \mathrm{IMF}$, available at https://www.imf.org/external/np/pp/eng/2010/061110.pdf, accessed on 15.05.2014. 


\section{Basel Committee on Banking Supervision (BCBS)}

The Cross Border Bank Resolution Group (CBRG) of the BCBS $^{83}$ developed a set of recommendations ${ }^{84}$ that resulted from its follow-up work on the identification of the lessons learned from the global financial crisis which began in 2007. In particular, some of the events during the crisis revealed gaps in intervention techniques and the absence in many countries of an appropriate set of resolution tools, such as wider powers to national authorities to deal with financial institutions at a preventive stage, the authority to create bridge banks, to transfer assets and liabilities to other solvent institutions, and to hold managers accountable. The report advocates the harmonization of current insolvency regimes not by supranational (binding or non-binding) agreements, but by granting regulators substantially similar regulatory powers.

During the resolution process, each country should have a mechanism to fund the ongoing operations of a cross-border financial institution. The funding mechanism might take the form of a deposit insurance fund or a public funding mechanism that would be reimbursed by an industry assessment. The BCBS Report did not provide any indication on how the costs of funding should be allocated or coordinated among the relevant national authorities. The BCBS Report, however, did note that effective crisis management and resolution of cross-border financial institutions required a clear understanding by the different national authorities of their respective responsibilities for supervision, liquidity provision, crisis management, and resolution of cross-border firms.

Another important role for effective supervision of international banking groups was allocated to supervisory colleges, since they can enhance information-sharing among supervisors, help the development of a shared agenda for addressing risks and vulnerabilities and provide a platform for communicating key supervisory messages among college members. ${ }^{85}$ In June 2014 , the BCBC issued its final Principles for effective supervisory colleges ${ }^{86}$ with great emphasis on: ongoing collaboration and information-sharing; the balance between core college effectiveness and host involvement; the ideas that home and host supervisors should put in place appropriate mechanisms and sufficient resources for effective and timely information exchange, should agree on what types of feedback they provide to banks and how they differentiate between banks that are systemically important banks or not, and how they provide guidance on communication and coordination. ${ }^{87}$

\section{Resolution: Supranationalism or Convergence}

The objective of resolution includes collective procedures that allow a debtor, who is unable to pay creditors, to resolve debt through the reorganization or the allocation of the debtor assets among all creditors in an equitable manner. ${ }^{88} \mathrm{~A}$ bank failure resolution strives to balance among numerous public

${ }^{83}$ BCBS is a committee of banking supervisory authorities that was established by the Central Bank governors of G10 in 1974, providing a forum for regular cooperation on banking supervisory matters. Its objective is to enhance understanding of key supervisory issues and improve the quality of banking supervision worldwide. The Committee also frames guidelines and standards in different areas - some of the better known among them are the international standards on capital adequacy, called the Core Principles for Effective Banking Supervision and the Concordat on cross-border banking supervision. The Committee's members come from Argentina, Australia, Belgium, Brazil, Canada, China, France, Germany, Hong Kong SAR, India, Indonesia, Italy, Japan, Korea, Luxembourg, Mexico, the Netherlands, Russia, Saudi Arabia, Singapore, South Africa, Spain, Sweden, Switzerland, Turkey, the United Kingdom and the United States. The Committee's Secretariat is located at the Bank for International Settlements (BIS) in Basel, Switzerland.

${ }^{84}$ See Basel Committee on Banking Supervision (BCBS), Report and Recommendations of the Cross-border Bank Resolution Group, March 2010, available at: http://www.bis.org/publ/bcbs169.pdf, accessed 16 June 2014.

${ }^{85}$ See Basel Committee on Banking Supervision, Good practice principles on supervisory colleges, 12 October 2010 , available at http://www.bis.org/publ/bcbs177.htm, accessed 16 June 2014.

${ }^{86}$ See Basel Committee on Banking Supervision, Principles for effective supervisory colleges, 26 June 2014, available at http://www.bis.org/publ/bcbs287.pdf, accessed 30 June 2014. The guidelines replace the Good practice principles on supervisory colleges, as there was a commitment to revise them after a period of practical implementation experience.

${ }^{87}$ Ibid., 2-3.

${ }^{88}$ Hüpkes and Devos (2011), 17.04. 
and private objectives, including: maintaining strong incentives to meet contractual obligations, treating different similarly situated claims equitably (pari passu), preventing inter-creditor competition from reducing the value of the defunct firm, maintaining the positive externalities associated with the operation of the insolvent financial institutions, preventing adverse social consequences and costs resulting from financial failure. ${ }^{89}$

Resolution planning is the key to an effective cross-border insolvency framework as it provides ready-to-hand plans for orderly resolution in the event of illiquidity or insolvency. It also serves as some kind of a preventive measure as the annual review process ensures financial institutions keep up with their own structural development, including: ascertaining the location of a bank's assets; the operations of set-off and netting; the differential nature of deposit protection schemes for various national and international entities; and the fact that supervisory ring-fencing and different national insolvency rules can affect returns to creditors.

There are two ways in which a cross-border insolvency framework can be set up: either by drawing supranational legal rules for an integrated and coherent framework or by convergence of national resolution procedures.

\section{Supranational Legal Framework}

A far-reaching approach that aims to converge legal norms with commercial reality would be a supranational framework, designing the framework as a binding legal instrument or as an international treaty ratified by all relevant home and host countries. This framework would designate the competent national resolution authorities for the resolution proceedings of all competent parts of the bank or, alternatively, establish a supranational authority in charge of resolution. ${ }^{90}$ As the structure of large cross-border banks is typically a financial group or holding with numerous bank and non-bank financial subsidiaries, which often operate in an integrated manner, this framework would also need to provide for a mechanism to resolve the bank's subsidiary in a coordinated and integrated manner. ${ }^{91}$

While a crisis generally gives the incentive for cooperation, when it comes to the benefit of domestic stakeholders of a global group (territorial approach or ring fencing), national authorities are reluctant to commit to cooperative solutions when national creditors would be worse off than in the resolution of a foreign bank's domestic operations under foreign law than had the domestic regulation simply been wound up under the applicable national laws. This contrasts the universal approach that recognizes the wholeness/unity of a legal entity across borders and provides for a process of mutual recognition of measures across borders. The treatment of a bank, with its foreign branches, needs to be distinguished from the situation when a bank operates through separate legal entity (subsidiaries) in foreign jurisdictions. Universality for instance is still fiercely challenged by the rest of the world in view of the surrender of sovereignty it implies from a host country's perspective, as well as the risk of seeing the various priorities and liens given by the main jurisdiction being expanded and diluting the claims of creditors of foreign branches.

Unlike branches or representative offices, subsidiaries are indeed separately incorporated legal entities under the corporate law of the respective jurisdiction. Subsidiaries may be subject to consolidated supervision by the home authority of the cross-border financial institution. However, the authorities of the chartering jurisdiction remain subject to first-line responsibility and resolution of the subsidiary. It is especially in an insolvency context that the situation of branches should be distinguished from subsidiaries. Each subsidiary has to be resolved separately; by contrast, foreign branches may in some jurisdictions be resolved by a single process under the insolvency regime of the main office's jurisdiction.

\footnotetext{
${ }^{89}$ Hüpkes and Devos (2011), 17.04. Santomero and Hoffmann (1998), 7.

${ }^{90}$ Hüpkes and Devos (2011), 17.35.

${ }^{91}$ Hüpkes and Devos (2011), 17.35.
} 
This solution would ensure the equitable treatment of all creditors, depositors, counter-parties and shareholders of group entities, regardless of the jurisdiction under which they are located. This would, in particular, require the careful assessment of intra-group asset transfers. ${ }^{92}$ The implementation of such a framework would obviously require major changes to national bank resolution frameworks, including the areas of commercial and property law. It would also raise important conceptual problems related to corporate separateness and the treatment of group interest. Having a common framework for resolution in place may not be enough. It might be necessary to address the many practical problems that arise in a complex cross-border resolution because of the inherent complexity of groups, the difficulty of obtaining information because of badly maintained record-keeping and risk-management systems, the necessity of identifying assets, liabilities, and counterparties on a legal entity basis, and sorting out inter-company transactions.

In order to implement a supranational framework, it needs a clear and coherent understanding on how the losses would be allocated in a crisis and how the public burden would be shared for the case of resolving a cross-border financial institution. Countries will be unwilling to surrender powers to another authority or supranational body if they risk being left with a disproportionate share of the burden. It is rather unlikely that such an agreement will be achieved on a global scale in the near or medium future.

\section{Convergence and Coordination}

As national legislators have adopted national resolution regimes in the aftermath of the financial crisis, an approach that favors convergence of national or regional resolution frameworks may be more effective in making progress for a broader cross-border insolvency framework for financial institutions, especially since the regulatory and supervisory processes already exist at a regional level in the US and European Union. Such an approach would place greater reliance on existing but enhanced national resolution frameworks and would seek to achieve progress mainly by focusing on challenges of a high degree of legal uncertainty and unpredictability arising from the fragmented landscape of different resolution frameworks, and the inconsistencies across countries relating to intervention and a restructuring mechanism that complicate cross-border coordination. ${ }^{93}$

Resolution planning as a mandatory part of the supervisory process should be challenged by the supervisory authority when evaluating the living wills of financial institutions, imposing predictability and legal certainty in case of a distress situation and eventual failure. ${ }^{94}$ If done consistently, planning a resolution will have a significant impact on the way national authorities regulate and supervise crossborder banks in the future. In order to reach that goal, certain measures have to be taken.

\section{a) Information sharing}

Sharing information on resolution plans with a common supervisory authority on a supranational level as implemented by the ECB can provide for a steep learning curve for national supervisors. It may cross-fertilize resolution measures and lead to the convergence of frameworks. In addition, it may also affect the way institutions operate and organize themselves. While it will never be possible to anticipate all the eventualities of financial or market distress, resolution planning gives national authorities and financial institutions a clear understanding of how the many different corporate entities would be handled in a crisis and how different national resolution regimes would interact, enabling them to identify actions that could be taken ex ante to facilitate resolution and reduce their systematic impact. Such a process would also ensure that national authorities as well as financial institutions acquaint themselves with the insolvency measures of other countries and be prepared for the worst case scenario. Sooner or later, such an approach would lead to a better understanding of the impact

\footnotetext{
${ }^{92}$ See Allen et al (2011), p. 41 questioning the soundness of the existing regulations, advocating for more detailed disclosure of all the transactions between the parent bank and its subsidiaries.

${ }^{93}$ Hüpkes and Devos (2011), 17.39.

${ }^{94}$ Hüpkes and Devos (2011), 17.40.
} 
and interactions of universality - or territoriality-based systems ${ }^{95}$ - prompting authorities to review the rationale of their own approaches and possibly consider legal changes that would lead to the convergence of national resolution regimes.

\section{b) Understanding Structural Complexity}

A better understanding of legal measures in different jurisdictions would also force managers to think much more carefully about the complex financial structures created within their organizations and the extent to which contractual obligations place substantial constraints on the choices that the authorities have to face in the event that reorganization measures need to be undertaken. If done properly, resolution planning should help to reduce the moral hazard associated with large cross-border financial institutions and should convince banks and market participants that a failing institution can be wound down in an orderly manner even though the wind-down may not necessarily be neutral for all stakeholders. ${ }^{96}$

\section{c) Location of the Centre of Main Interest (COMI)}

Determining the COMI of the financial conglomerate in the process of resolution planning will enable a coherent chain of command in case of financial distress. One has to keep in mind though that those financial holdings may be set up in offshore countries to avoid transparency. The national authorities have to ensure judicial and legal transparency in the resolution planning.

\section{d) Protocols for Resolution Planning}

In order to foster the coordination and cooperation of national authorities, the resolution planning should include court-based protocols for cross-border insolvencies. There have been examples of court-based cooperation in complex corporate cross-border cases ${ }^{97}$ that could serve as a blueprint for financial institutions.

It is hardly realistic to achieve a harmonization of all national bank resolution frameworks, however, efforts should be made to reach convergence in a few critical areas which could greatly enhance the prospects of achieving a coordinated, coherent and timely solution across borders. First, an early intervention could preserve value that minimizes losses and market disruptions and ensures continuity of essential business operations if, in all jurisdictions, the competition authority had the power to intervene early before an insolvency threshold is met. Second, national resolution regimes should provide for special resolution power for national or regional authorities (like the European SRM), while certain restructuring and resolution tools should facilitate the creation of temporary bridge bank structures and/or transfer assets and liabilities to another entity, supporting a coordinated solution. Third, the national authority's legal capacity to cooperate across borders - such as broad informationsharing, the possibility to recognize proceedings - facilitates the transfer of assets across borders, and assists a restructuring or resolution. Fourth, the ranking of (certain classes of) debt in insolvency: A common understanding of the ranking of certain creditor positions, such as, for example, the treatment of depositors, could help to achieve greater predictability and more consistent resolution across borders. ${ }^{98}$

\footnotetext{
${ }^{95}$ IMF, Resolution of Cross-Border Banks - A Proposed Framework for Enhanced Coordination IMF, p. 10.

${ }^{96}$ IMF, Resolution of Cross-Border Banks - A Proposed Framework for Enhanced Coordination IMF, p. 12.

${ }^{97}$ Halliday and Carruthers (2009), 47ff. Maxwell's group court-based protocol from 1991 stated its objective as harmonizing the proceedings of the UK and US court involved in order to facilitate a rehabilitation and reorganisation of Maxwell Corp. It was followed by the IBA Cross-Border Insolvency Concordat in 1995 and was founded on ten principles, see International Bar Association, available http://www.ibanet.org/About_the_IBA/IBA_instruments.aspx, accessed 10.06.2014.

${ }^{98}$ Hüpkes and Devos (2011), 17.41.
} 


\section{Conclusion}

A well-designed legal framework is important for the functioning of financial markets and this is particularly true in times of global financial trouble. Although much noise has been made in the aftermath of the financial crisis, not much action has taken place. The issue of international standards addressing cross-border bank insolvency is very much at a point of work in progress. There is no such framework yet with regard to cross-border financial institutions, neither at the European level nor at the international level. As a consequence, the interests of domestic and foreign authorities might not be fully aligned.

National authorities are usually only concerned about a particular subsidiary under their jurisdiction. Whenever the losses generated by the failure of a foreign subsidiary are considered to be small, they decide in favor of a liquidation procedure that benefits local creditors. These decisions tend to avoid lengthy restructuring processes being undertaken in another country. Achieving a good level of co-ordination requires a sound legal and regulatory framework at the national level. However, this is not easy to attain. Common rules on appropriate intervention tools, creditor safeguards, robust rules on deposit priority and non-discrimination against foreign creditors are all factors that need to be brought into play to ensure a good result. Overall, until supervisory measures aimed at identifying problem banks at an early stage are well-implemented, the resolution process will continue to be the ultimate response to bank failures in order to break out of the current economic cycle.

Resolutions relating to inter-jurisdiction conflicts still rely on the willingness of national authorities to co-operate with each other, as national efforts will fizzle out in the end and will lead to competitive disadvantages. It would be desirable that a single authority take the lead in coordinating responses - an authority with powers to implement a coherent and effective framework, not one based on the smallest common denominator. Closing unviable banks and recapitalizing and restructuring viable ones is inherently painful and politically charged. Structures to manage failed banks and assets remain inadequate in the most relevant economies such as the EU and the US.

To respond to the challenges arising from global complex financial institutions means the creation of an overarching global framework that would include a harmonized set of both procedural and substantive rules, however, the complexity of implementing such a proposal is enormous. The resolution planning process could be an appropriate measure to increase transparency among different national authorities and enhance the transparency in complex institutions by better understanding how national resolution frameworks operate to prepare for the contingency of a financial failure. Determining where the COMI is located and preparing a court-based protocol for the respective jurisdictions that would be affected in the case of a failure could be a valuable step forward in dealing with the struggle of financial institutions in the future. 


\section{References}

\section{Bibliography}

Admanti, Anat R., and Martin Hellwig. The Bankers' New Clothes: What's Wrong with Banking and What to Do about it, Princeton University Press, 2013.

Allen, Franklin, Xian Gu and Oskar Kowalewski. "Corporate Governance and intra-group transactions in European bank holding companies during the crisis", 13 February 2011, Available at http://finance.wharton.upenn.edu/ allenf/download/Vita/AKX_final_ok.pdf, accessed 14.05.2014.

Andrianova, Svetlana, Panicos Demetriades, and Anja Shortland. "Government Banks and Growth: Theory and Evidence." In Complexity and Institutions: Markets, Norms and Corporations, ed. Masahiko Aoki, Ken Binmore, Simon Deakin, and Herbert Gintis, pages 214 - 242, Palgrave Macmillan, 2012.

Barth, James R., R. Dan Brumbaugh Jr., and Glenn Yago (eds.). Restructuring Regulation and Financial Institutions, Kluwer Academic Publishers, 2001.

Brealey, Richard and Stewart Myers, Principles of Corporate Finance, 2nd Edition, McGraw Hill, 1984.

Brummer, Chris. Soft Law and the Global Financial System: Rule Making in the 21st Century, Cambridge University Press, 2012.

Buckley, Ross B., and Douglas W. Arner. From Crisis to Crisis: The Global Financial System and Regulatory Failure, International Banking and Finance Law Series, Wolters Kluwer Law \& Business, August 2011.

Buljevich Esteban C. (ed.). Cross Border Debt Restructuring: Innovative Approaches for Creditors, Euromoney Institutional Investor PLC, 2005.

Busch, Andreas. Banking Regulation and Globalization, Oxford University Press, 2009.

Cairns, Ann. "Breaking the Insolvency Mould", International Corporate Rescue, 6(2), 2009, 115. Available at http://www.chasecambria.com/site/journal/articlephp?id=384, accessed 14.05.2014.

Caprio Jr., Gerard, William C. Hunter, George G. Kaufmann, and Danny M. Leipziger. Preventing Bank Crises: Lessons from the Recent Financial Global Bank Failures; Proceedings of a Conference - Sponsored by the Federal Reserve Bank of Chicago and the Economic Development Institute of the World Bank, EDI Development Studies, 1998.

Caprio Jr., Gerard, William C. Hunter, and George G. Kaufmann (eds.). Cross-Border Banking Regulatory Changes, World Scientific Studies in International Economics, 2006.

Carmassi, Jacopo and Stefano Micossi. Time to Set Banking Regulation Right, Centre for European Policy Studies (CEPS), 2012.

Claessens, Stijn, Richard Herring, and Dirk Schoenmaker (2010). A Safer World Financial System: Improving the Resolution of Systemic Institutions, Geneva Reports on the World Economy 12, International Center for Monetary and Banking Studies (ICMB).

Corrigan, E. Gerald. Are Banks Special?, Federal Reserve Banks of Minneapolis and New York, published January 1, 1983, https://www.minneapolisfed.org/pubs/ar/ar1982a.cfm, accessed 14 April 2014.

De Rosa, Luigi (ed.). International Banking and Financial Systems: Evolution and Stability, Ashgate Publishing Limited, 2003.

Draghi, Mario, Speech at quarterly hearing with the parliament's economic and monetary affairs committee, Monday, 17. December 2012. Available at http://euobserver.com/economic/ 118553, accessed on 26.05.2014. 
Easterbrook, Frank H (1990)." Is Corporate Bankruptcy Efficient?", 27 Journal of Financial Economics., 411-17.

Evanoff, Douglas D., and George G. Kaufmann (eds.). Systemic Financial Crisis: Resolving Large Bank Insolvencies, World Scientific Publishing, 2005.

Fama, Eugene. Efficient Markets: A review of Theory and Empirical Work. Journal of Finance, 1970, 25 (2), 383-417.

Frankfurter Allgemeine Zeitung (FAZ). „Die Bankbranche im Euroraum schrumpft langsam“, Nr. 258, 06. November 2013, p. 18.

Frankfurter Allgemeine Zeitung (FAZ). „Aufseher verschärfen Regeln für Bankentestamente“, Nr. 191, 19. August 2014, p. 23.

Finch, Vanessa. "Corporate rescue processes: the search for quality and the capacity to resolve", J.B.L. (2010) 502-21.

Fiordelisi, Franco, Philip Molyneux, and Daniele Previati (eds.). New Issues in Financial and Credit Markets, Palgrave Macmillan studies in banking and financial institutions, 2010.

Fitzpatrick Thomas J. IV, and James B. Thomson. An End to Too Big to Let Fail? The Dodd-Frank Act's Orderly Liquidation Authority, Federal Reserve Bank of Cleveland, 01.05.11, http://www.clevelandfed.org/research/commentary/2011/2011-01.cfm, accessed 16 April 2014.

Fletcher, Ian (ed.). Cross-Border Insolvency: National and Comparative Studies, Reports Delivered at the XIII International Congress of Comparative Law, Montreal 1990), J.C.B. Mohr (Paul Siebeck), Tübingen, 1992.

Fratianni, Michele, Paolo Savona, and John J. Kirton. Governing Global Finance: New Challenges, G7 and IMF Contributions, Global Finance Series, Ashgate Publishing Limited, 2002.

Giovanoli, Mario, and Gregor Heinrich (eds). International Bank Insolvencies: A Central Bank Perspective, International Banking, Finance and Economic Law Series, Kluwer Law International, 1999.

Gorton, Gary B. Misunderstanding Financial Crises: Why We Don't See Them Coming, Oxford University Press, 2012.

Grant, Wyn, and Graham K. Wilson (ed.). The Consequences of the Global Financial Crisis - The Rhetoric of Reform and Regulation, Oxford University Press, 2014.

Grossman, Sanford, and Joseqph Sticklitz. On the Impossibility of Informationally Efficient Markets. American Economic Review, 198070 (3), 393-408.

Gurlitt, Elke. "The ECB's relationship to the EBA", EuZW 2014, 14-18.

Haentjens, Matthias, and Bob Wessels (ed.). Bank Recovery and Resolution, eleven international publishing, 2014.

Hoflich, Peter. Banks at Risk: Global Best Practices in an Age of Turbulence, John Wiley \& Sons (Asia) Pte. Ltd., 2011.

Huertas, Thomas F. Too Big to Fail, Too Complex to Contemplate: What to Do about Systemically Important Firms, Paper presented at the Financial Markets Group conference, "Too Big to Fail, Too Interconnected to Fail?" London 2009. Available at http://www.lse.ac.uk/fmg/documents/events/conferences/2009/tooBig/Huertas.pdf. - The Road to Better Resolution - From Bail-Out to Bail-In, Revised Draft of Financial Markets Group Paper Series, Special Paper 195. Available at http://www.lse.ac.uk/fmg/events/conferences/past-conferences/2011/DBWorkshop_14Mar 2011/4-ThomasHuertas.pdf. 
Hüpkes, Eva. "Complicity in Complexity: What to Do About the "Too-Big to-Fail" Problem", Butterworth's Journal of International Banking and Financial Law, October 2009, 515-18.

Hüpkes, Eva and Diego Devos. "Cross-Border Bank Resolution: A Reform Agenda." In International Monetary and Financial Law, ed. Mario Giovanoli and Diego Devos, Oxford University Press, $2010,359-377$.

Kolb, Robert W. (ed.). Lessons from the Financial Crisis: Causes, Consequences, and Our Economic Future, The Robert W. Kolb series in finance, John Wiley \& Sons, Inc., 2010.

Krozner, Randall S. and Robert J. Shiller. Reforming U.S. Financial Markets - Refelctions Before and Beyond Dodd-Frank, The MIT Press, Cambridge, 2011.

Macdonald, Kate, Shelly Marshall, and Sanjay Pinto (eds.). New Visions for Market Governance: Crisis and Renewal, Routledge/Challenges of Globalisation, Routledge, 2012.

Miller, Geoffrey P., and Fabrizio Cafaggi. The Governance and Regulation of International Finance, Edward Elgar Publishing Limited, 2013.

Mitchell, Lawrence E., and Arthur E. Wilmarth, Jr. (ed.). The Panic of 2008 - Causes Consequences and Implications for Reform, Edward Elgar Publishing Limited, 2010.

Neumann, Kerstin. "The supervisory powers of national authorities and cooperation with the ECB - a new epoch of banking supervision", EuZW 2014, 9-14.

Laeven, Luc and Fabian Valencia. "Systemic Banking Crises Database: Resolution of Banking Crises", International Monetary Fund (IMF) Working Paper, WP/10/246, Washington, DC, 2010.

Renner, Moritz. "Death by Complexity - the Financial Crisis and the Crisis of Law in World Society", in Kjaer, Poul F., and Gunther Teubner, Alberto Febbrajo (ed.). The Financial Crisis in Constitutional Perspective: The Dark Side of Functional Differentiation. Bloomsbury Publishing, 2011.

Santomero, Anthony M., and Paul Hoffmann. Problem Bank Resolution: Evaluating the Options, The FAIR-Wharton Conference, Banking Problems in Japan, August 1996. Available at http://fic.wharton.upenn.edu/fic/papers/98/9805.pdf, accessed 10.05.2014.

Solidoro, Silvia. "Cross-Border Bank Insolvency Regimes and Financial Supervision in the EU." In Legitimacy and Effectiveness in Global Economic Governance, ed. Biagio Bossone, Maria Chiara Malaguti, Susanna Cafaro, and Saverio Di Benedetto, Cambridge Scholars Publishing, 2013.

Schuster, Gunnar. "The banking supervisory competences and powers of the ECB", EuZW 2014, 3-9.

Watson Alan. "Legal Change: Sources of Law and Legal Culture", 131 U. Penn. L. Rev. (1983) 112157.

Watson, Alan. Society and Legal Change, 1977.

Wilks, Stephen. The Political Power of the Business Corporation, Edward Elgar Publishing Ltd., 2013. 

